\title{
SCREENING OF OKRA VARIETIES FOR RESISTANCE TO OKRA YELLOW VEIN MOSAIC DISEASE UNDER FIELD CONDITIONS
}

aSabir I. Khoso, aJamal-U-Ddin Hajano, aAli A. Lakho, aManzoor A. Abro, bKhalid H. Dhiloo, aKhadim H. Wagan, bFahad N. Khoso, 'Aftab R. Jarwar, aSuman T. Qazi, dSyed Rizwan

a Department of Plant Pathology, Faculty of Crop Protection, Sindh Agriculture University, Tandojam 70600, Pakistan.

${ }^{b}$ Department of Entomology, Faculty of Crop Protection, Sindh Agriculture University, Tandojam 70600, Pakistan.

${ }^{c}$ Department of Plant Protection, Faculty of Crop Protection, Sindh Agriculture University, Tandojam 70600, Pakistan.

${ }^{d}$ Faculty of Eastern Medicine, Hamdard University, Karachi 76400, Pakistan.

\section{A R T I C LE I N F O}

\section{Article History}

Received: February 01, 2021

Revised: March 06, 2021

Accepted: March 10, 2021

\section{Keywords}

Okra

Okra yellow vein mosaic

disease

Resistance screening

Whitefly

Bemisia tabaci

Varieties

\section{A B S T R A C T}

Okra (Abelmoschus esculentus L.) can contract okra yellow vein mosaic disease (OYVMD) caused by Bhendi yellow vein mosaic virus (genus: Begomovirus and family: Geminiviridae), vectored by whitefly (Bemisia tabaci). This study was carried out to screen okra varieties for resistance to OYVMD and to determine the correlation of vector population with the severity of the disease. Six varieties namely, Tulsi, Durgah, Sabz Pari, Sarahariya, Ramaan Kirshna and Pooja were grown under field conditions at localities of Shahpur, Tando Adam and Peer Kathi during rabi (winter cropping) and kharif (summer cropping) seasons during 2016 and 2017, respectively. The first incidence percent of the disease was recorded in the $8^{\text {th }}$ week during rabi and the $6^{\text {th }}$ week during kharif growing season. The Tulsi variety remained disease-free during both growing seasons. A significantly lower disease incidence \% was recorded in Sabz Pari (29.32\%) and Sarahariya (30.09\%) varieties than Durgah, Ramaan Kirshna and Pooja during the rabi growing season. Both varieties were disease-free during the kharif season. There was remarkable variation in disease severity recorded in okra varieties at different trials during rabi and kharif seasons using a 0-6 rating scale (i.e., $0=$ The disease-free plants, $1=1-10 \%$ vein clearing, $2=11-25 \%$ vein yellowing of small leaves , $3=26-50 \%$ yellow network on some leaves, $4=51-60 \%$ yellow network on all leaves, $5=60-70 \%$ complete leaves turn yellow or cream color and $6=>70 \%$ plant stunted, deformed and small fruit and whole plants becomes colorless). Whitefly appeared in the $5^{\text {th }}$ week during the rabi and $4^{\text {th }}$ week during the kharif growing seasons. Vector population during the rabi growing season was significantly higher than in the kharif season. There was a nonsignificant relationship between disease severity and whitefly population in Ramaan Kirshna, Sarahariya, and Sabz Pari varieties. The disease severity in the Pooja variety showed a significant relationship with vector population, but only in the Tando Adam trial $\left(R^{2}=0.7455, P=0.0084\right)$, whereas the Durgah variety showed a significant relationship between disease severity and vector population in Shahpur $\left(R^{2}=0.6615, P=0.0267\right)$ and Tando Adam trials $\left(R^{2}=0.8235, P=0.0018\right)$. The same variety showed a nonsignificant relationship between disease severity and vector population in the Peer Kathi trial. It is concluded that Sabz Pari and Tulsi varieties are resistant to the disease.

Corresponding Author: Jamal-U-Ddin Hajano

Email: jhajano@sau.edu.pk

(C) The Author(s) 2021. 


\section{INTRODUCTION}

Okra (Abelmoschus esculentus L.) is placed in the Malvaceae family; it originated in tropical Africa but can be cultivated in different regions of the world (Ali et al., 2012). Pakistan, Turkey, Iran, western Africa, Yugoslavia, Bangladesh, Afghanistan, India, Burma, Japan, Malaysia, Brazil, Ghana, Ethiopia, Cyprus, and the southern United States are the okra-producing countries in the world. Approximately 9.953537 million tonnes of okra is produced worldwide (FAOSTAT, 2020). In Pakistan, the crop is cultivated on an area of 15713 hectares, with an annual production of 120637 tonnes. Approximately 4969 hectares are under cultivation in Sindh province of Pakistan, which produces 19731 tonnes of okra (GOP, 2020). Although okra is grown as a kharif (summer crop) vegetable in Pakistan, recently it is also grown as a rabi (winter crop) vegetable.

The okra crop can be affected by various fungal, bacterial, viral, and nematode diseases. Among viral diseases, okra yellow vein mosaic disease (OYVMD) caused by Bhendi yellow vein mosaic virus (BYVMV, genus: Begomovirus and family: Geminiviridae) is the most important and devastating disease (Prakasha et al., 2010). Generally, whitefly (Bemisia tabaci) transmits the virus in a persistent circulative nonpropagative manner (Sangeeta and Tiwari, 2017). The disease was first reported on okra plants in 1924 in India and Sri Lanka (Kumar and Raju, 2017). Okra plants infected with BYVMV show symptoms of vein clearing, followed by yellowing of the whole leaf and reduction in leaf and fruit sizes, leading to a significant decrease in production. Approximately $96 \%$ yield losses due to the disease are reported, which are highly dependent on the time of infection or stage of plant being infected (Pun and Doraiswamy, 1999). The virus poses a serious threat to okra cultivation worldwide including in Sindh, Pakistan owing to its long-term survival in the insect vector, highly efficient transmission through the insect vector and overlap cropping. In the Hyderabad district, Sindh-Pakistan, the BYVMV significantly reduces all plant growth and yield parameters under natural infection conditions (Khaskheli et al., 2017). Kumbhar (2017) concluded from his survey study that OYVMD prevails in districts of Hyderabad, Tando Allahyar, Matiari, and Sanghar (Sindh-Pakistan) with high incidence and severity. There is a wide range of management practices for suppressing disease under field conditions. However, incorporation of resistant varieties into a disease management program is the most efficient, cost-effective, and feasible strategy to suppress plant diseases and this strategy has been used for centuries. It may suppress initial disease and/or suppress the rate of epidemic development. For such purpose, various okra varieties have been screened against BYVMV and analyzed for their relationship between susceptibility and environmental factors (Siddique et al., 2016). Similarly, Ali et al. (2005b) used different varieties of okra, i.e., Pahuja, Safal, Subz Pari, and Surkh Bhindi, for measuring disease severity and analyzing the correlation with vector population size and environmental conditions. However, change in susceptibility/resistance in plants may occur in time or space dimension due to environmental conditions, availability of the vector insect or virus isolate virulence. Therefore, continuous varietal screening for new resistance sources to complement and strengthen the resistance of elite cultivars is essential to circumvent possible threats. Incidence and severity are easy, economic parameters for disease assessment and are sufficient to indicate relationship with yield losses in crops (Cooke et al., 2006; González-Pérez et al., 2011). Thus, the present study was conducted to screen different commercial varieties of okra for resistance/susceptibility to Bhendi yellow vein mosaic viral disease under field conditions and determine its correlation, if any, with vector (i-e whitefly) population size.

\section{MATERIALS AND METHODS}

\section{Experimental sites}

Experiments were conducted at localities of Shahpur (District Matiari), Tando Adam (District Sanghar), and Peer Kathi (District Tando Allahyar) in Sindh province of Pakistan under natural inoculation conditions.

\section{Planting material and experiment design}

Six varieties namely, Tulsi, Durgah, Sabz Pari, Sarahariya, Ramaan Kirshna, and Pooja, were tested for resistance/Susceptibility to BYVMVD. Trials were conducted in rabi (winter) and kharif (summer) seasons during 2016 and 2017, respectively. A total of 30 plants of each variety were maintained after thinning with three replications (10 per repeat, 3 repeats $=30$ plants) in a completely randomized design in the same experimental plot.

\section{Virus detection}

Total DNA was extracted from leaves showing typical symptoms of the disease by the CTAB method with 
necessary modifications (Ghosh et al., 2009). A degenerate primer set (GEM-F: 5'ATRRTHTGGATGGAYGARAACAT-3'; GEM-R: 5'AAATCCCCTNTATTTCAAARAT-3') designed by Roy et al. (2015) was used to amplify a 760 bps fragment that overlapping the putative AV1, AC3, and AC2 of the viral genome. Amplified PCR products were purified using the UltraClean ${ }^{\circledR}$ PCR Clean-Up kit (MoBio, USA) and were sent to Sogo Ltd. for nucleotide sequencing. The obtained sequences were tested for similarity to BYVMVD using Blastn on the NCBI website (http://www.ncbi.nlm.nih.gov/).

\section{Observation and measurements}

Observations were taken for disease incidence \% (number of symptomatic plants), severity (portion of plant showing symptoms), and whitefly population size (nymph and adult whiteflies) on a weekly basis after date of sowing. The disease incidence percentage was calculated by dividing the number of diseased okra plants by the total number of plants observed for the disease. A rating scale of 0-6 (i.e., $0=$ The disease-free plants, $1=1-10 \%$ vein clearing, $2=11-25 \%$ vein yellowing of small leaves , $3=26-50 \%$ yellow network on some leaves, $4=51-60 \%$ yellow network on all leaves, $5=60-70 \%$ complete leaves turn yellow or cream color and $6=>70 \%$ plant stunted, deformed and small fruits and the whole plants becomes colorless) was used to assess disease severity (Ali et al., 2005a). Each plant was rated and then averaged in the group of 10 plants to represent one replication and there were three such replications of that variety at a given location.

\section{Vector scouting}

Nymphs and adult whiteflies were counted on upper, middle, and lower leaves of three plants, respectively, at the time of visual disease assessment as described by Akram et al. (2013), then obtained values were processed same as for incidence and severity values of the disease as mentioned above.

\section{Statistical analysis}

A multifactorial ANOVA was performed to analyze significant difference in disease incidence and whitefly population and the interaction of varieties $\times$ trials $\times$ season $\times$ time of assessment. An LSD test $(\alpha=0.005)$ was performed using analytical software (STATISTIX v. 8.1 software). The relationship between OYVMD and insect vector population size was determined using PRISM v. 5.01 (Graph Pad Software).

\section{RESULTS}

\section{Virus detection}

Typical symptoms of BYVMV such as yellowing and vein clearing in leaf were observed in the diseased plants (Fig. 1 $\mathrm{A}$ and B). Amplification of degenerate sequence-specific primers of gemini-viruses showed a band of the expected length of 760 bps after gel electrophoresis of PCR products (Fig. 1C). Furthermore, sequence alignment showed $88 \%$ nucleotide identity to DNA-A segment of the Bhendi yellow vein mosaic virus isolate OK309-RAJ (complete sequence ID KT 390325-1). These results clearly showed that the plants were infected with the virus.

\section{Incidence of okra yellow vein mosaic disease in different okra varieties during rabi and kharif growing seasons}

Disease incidence percent results were recorded in the $8^{\text {th }}$ week after sowing during the rabi growing season. The Sabz Pari variety showed a significantly minimum incidence of $27.1 \%$ followed by Sarahariya and Ramaan Kirshna $(28.3 \%)$ in the $8^{\text {th }}$ week after sowing during the rabi season. The disease incidence showed a gradual increase in all the varieties until the $11^{\text {th }}$ week of assessment. In the $11^{\text {th }}$ week of assessment a significantly maximum incidence was recorded in Pooja (97.5\%), Durgah, and Ramaan Kirshna (96.2\%) and Sarahariya (93.8\%) followed by Sabz Pari (88.9\%) varieties (Table 1). The Tulsi variety was found to be disease-free during both growing seasons (Table 1). During the kharif season, the disease incidence was lower than that during the rabi season, but the disease appeared 2 weeks earlier in the $6^{\text {th }}$ week after sowing (Table 1). Although Sarahariya and Sabz Pari varieties were found to be diseased during the rabi season, the incidence was zero during the kharif season (Table 1). A significantly minimum incidence of $3.7 \%$ was recorded in the Ramaan Kirshna variety, followed by Pooja and Durgah $(16.0 \%)$ varieties in the $6^{\text {th }}$ week after sowing (Table 1). Similar to that in the rabi season, the disease incidence showed an increase with passage of time. During the last assessment of the disease in the $11^{\text {th }}$ week after sowing, a higher incidence of $67.9 \%$ was recorded in the Pooja variety, followed by Durgah (59.2\%) and Ramaan Kirshna (50.6\%) (Table 1). 
A

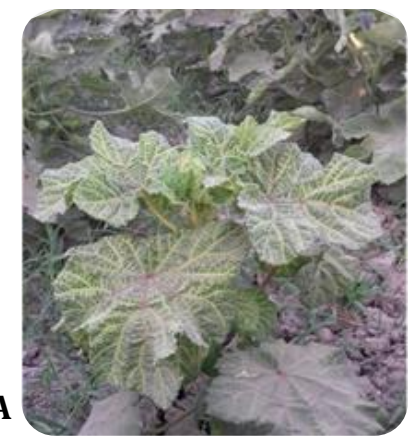

B

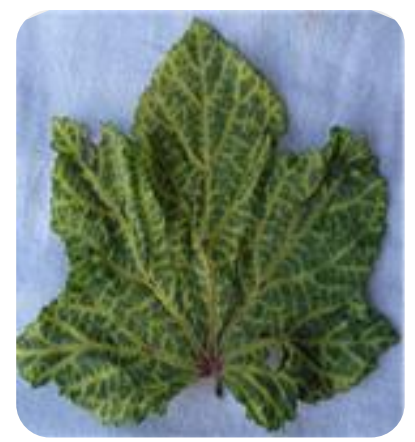

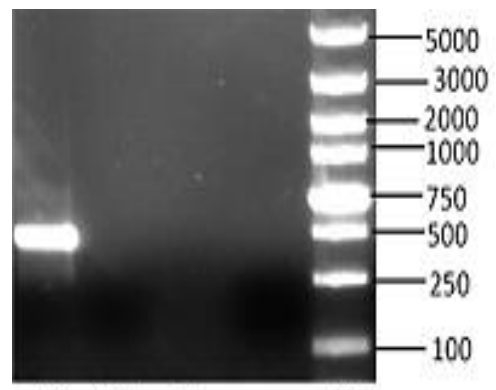

$\begin{array}{llllll}C & \$ 1 & \$ 2 & \$ 3 & -M\end{array}$

Figure 1. Symptoms of okra yellow vein mosaic disease and virus detection. (A) Plant of okra in the field showing yellowing, (B) the diseased leaf showing vein clearing, and (C) ethidium bromide stained 1\% agarose gel showing 760 bps band amplified from DNA, extracted from diseased leaf samples. Lane "S1-3" indicates amplification of a $760 \mathrm{bp}$ DNA band from the diseased leaf samples, "-" indicates water only template control, and "M" indicates DL2000 plus DNA marker.

Table 1. Yellow vein mosaic disease incidence in different okra varieties during rabi and kharif seasons.

\begin{tabular}{llcccccccc}
\hline \multirow{2}{*}{ Season } & Variety & \multicolumn{7}{c}{ Weeks after sowing } \\
\cline { 2 - 9 } & Pooja & $0.00 \mathrm{t}$ & $0.00 \mathrm{t}$ & $0.00 \mathrm{t}$ & $0.00 \mathrm{t}$ & $30.7 \mathrm{mn}$ & $92.6 \mathrm{a}-\mathrm{c}$ & $87.7 \mathrm{~cd}$ & $97.5 \mathrm{a}$ \\
& Durgah & $0.00 \mathrm{t}$ & $0.00 \mathrm{t}$ & $0.00 \mathrm{t}$ & $0.00 \mathrm{t}$ & $32.0 \mathrm{mn}$ & $87.7 \mathrm{~cd}$ & $90.1 \mathrm{bc}$ & $96.2 \mathrm{ab}$ \\
\multirow{3}{*}{ Rabi } & Ramaan Kirshna & $0.00 \mathrm{t}$ & $0.00 \mathrm{t}$ & $0.00 \mathrm{t}$ & $0.00 \mathrm{t}$ & $28.3 \mathrm{n}$ & $81.4 \mathrm{~d}$ & $96.2 \mathrm{ab}$ & $96.2 \mathrm{ab}$ \\
& Sarahariya & $0.00 \mathrm{t}$ & $0.00 \mathrm{t}$ & $0.00 \mathrm{t}$ & $0.00 \mathrm{t}$ & $28.3 \mathrm{n}$ & $58.0 \mathrm{fg}$ & $60.4 \mathrm{f}$ & $93.8 \mathrm{abc}$ \\
& Sabz Pari & $0.00 \mathrm{t}$ & $0.00 \mathrm{t}$ & $0.00 \mathrm{t}$ & $0.00 \mathrm{t}$ & $27.1 \mathrm{no}$ & $46.9 \mathrm{hij}$ & $71.6 \mathrm{e}$ & $88.9 \mathrm{c}$ \\
& Tulsi & $0.00 \mathrm{t}$ & $0.00 \mathrm{t}$ & $0.00 \mathrm{t}$ & $0.00 \mathrm{t}$ & $0.00 \mathrm{t}$ & $0.00 \mathrm{t}$ & $0.00 \mathrm{t}$ & $0.00 \mathrm{t}$ \\
\hline \multirow{3}{*}{ Kharif } & Pooja & $0.00 \mathrm{t}$ & $0.00 \mathrm{t}$ & $16.0 \mathrm{pq}$ & $25.9 \mathrm{no}$ & $37.0 \mathrm{~lm}$ & $45.7 \mathrm{ijk}$ & $53.0 \mathrm{gh}$ & $67.9 \mathrm{e}$ \\
& Durgah & $0.00 \mathrm{t}$ & $0.00 \mathrm{t}$ & $16.0 \mathrm{pq}$ & $21.0 \mathrm{op}$ & $37.0 \mathrm{~lm}$ & $42.0 \mathrm{jkl}$ & $44.4 \mathrm{ijk}$ & $59.2 \mathrm{fg}$ \\
& Ramaan Kirshna & $0.00 \mathrm{t}$ & $0.00 \mathrm{t}$ & $3.7 \mathrm{st}$ & $7.4 \mathrm{rs}$ & $17.2 \mathrm{pq}$ & $39.5 \mathrm{kl}$ & $43.2 \mathrm{jkl}$ & $50.6 \mathrm{hi}$ \\
& Sarahariya & $0.00 \mathrm{t}$ & $0.00 \mathrm{t}$ & $0.00 \mathrm{t}$ & $0.00 \mathrm{t}$ & $0.00 \mathrm{t}$ & $0.00 \mathrm{t}$ & $0.00 \mathrm{t}$ & $0.00 \mathrm{t}$ \\
& Sabz Pari & $0.00 \mathrm{t}$ & $0.00 \mathrm{t}$ & $0.00 \mathrm{t}$ & $0.00 \mathrm{t}$ & $0.00 \mathrm{t}$ & $0.00 \mathrm{t}$ & $0.00 \mathrm{t}$ & $0.00 \mathrm{t}$ \\
& Tulsi & $0.00 \mathrm{t}$ & $0.00 \mathrm{t}$ & $0.00 \mathrm{t}$ & $0.00 \mathrm{t}$ & $0.00 \mathrm{t}$ & $0.00 \mathrm{t}$ & $0.00 \mathrm{t}$ & $0.00 \mathrm{t}$ \\
\hline
\end{tabular}

* The disease incidence percent from the first to the third week of sowing was zero. Incidence values are presented in percentage. Alphabetical letters along with values indicate statistical differences among the values at $a=0.05$.

Sarahariya showed minimum incidence of $10.18 \%$, $32.40 \%$ and $47.70 \%$ in Tando Adam, Shahpur and Peer Kathi trials, respectively, during the rabi growing season, whereas during the kharif growing season, it was disease-free (Table 2). Similarly, there was $14.35 \%$, $29.63 \%$ and $43.98 \%$ incidence in the Sabz Pari variety in Tando Adam, Shahpur and Peer Kathi trials, respectively, during the rabi growing season (Table 2). Ramaan Kirshna showed $32.40 \%$ incidence in the Tando Adam trial, whereas there was increase in incidence up to $35.19 \%$ in Shahpur trial and $45.83 \%$ in Peer Kathi trial during the rabi growing season (Table 2). During the kharif growing season disease incidence of $15.74 \%$,
$17.13 \%$ and $27.78 \%$ was recorded in the Ramaan Kirshna variety (Table 2). There was no significant difference in the disease incidence \% in the Durgah variety (32.40 and $32.87 \%$ ) in the Tando Adam and Shahpur trials, but it was higher in Peer Kathi trial (49.53\%) during the rabi growing season (Table 2). During the kharif growing season, the Durgah variety showed 17.59, 30.56 and $34.26 \%$ disease incidence in Peer Kathi, Shahpur, and Tando Adam trials, respectively (Table 2). The same disease incidence of $34.72 \%$ was observed in the Pooja variety in Tando Adam during both growing seasons (Table 2), whereas in the Peer Kathi trial, it was higher, i-e., 49.07 and $17.59 \%$ during 
rabi and kharif growing seasons, respectively (Table 2). The disease incidence \% was higher (38.89\%) during the kharif and lower $(31.94 \%)$ during the rabi growing season (Table 2). The Tulsi variety was disease-free during both growing seasons at all the three locations of trials (Table 2).

Table 2. The incidence of okra yellow vein mosaic disease in different varieties during rabi and kharif seasons in Shahpur, Peer Kathi, and Tando Adam locations.

\begin{tabular}{clcc}
\hline \multirow{2}{*}{ Trial } & Variety & \multicolumn{2}{c}{ Season } \\
\cline { 2 - 4 } & Pooja & $31.94 \mathrm{~d}-\mathrm{f}$ & Kharif \\
\cline { 2 - 3 } Shahpur & Durgah & $32.87 \mathrm{~d}-\mathrm{f}$ & $38.89 \mathrm{c}$ \\
& Ramaan Kirshna & $35.19 \mathrm{~cd}$ & $30.56 \mathrm{e}-\mathrm{g}$ \\
& Sarahariya & $32.40 \mathrm{~d}-\mathrm{f}$ & $27.78 \mathrm{~g}$ \\
& Sabz Pari & $29.630 \mathrm{fg}$ & $0.00 \mathrm{j}$ \\
& Tulsi & $0.0000 \mathrm{j}$ & $0.00 \mathrm{j}$ \\
& Pooja & $49.07 \mathrm{a}$ & $0.00 \mathrm{j}$ \\
\hline \multirow{5}{*}{ Peer Kathi } & Durgah & $49.53 \mathrm{a}$ & $17.59 \mathrm{~h}$ \\
& Ramaan Kirshna & $45.83 \mathrm{ab}$ & $17.59 \mathrm{~h}$ \\
& Sarahariya & $47.70 \mathrm{ab}$ & $17.13 \mathrm{~h}$ \\
& Sabz Pari & $43.981 \mathrm{~b}$ & $0.00 \mathrm{j}$ \\
& Tulsi & $0.00 \mathrm{j}$ & $0.00 \mathrm{j}$ \\
& Pooja & $34.72 \mathrm{~d}$ & $0.00 \mathrm{j}$ \\
\hline \multirow{3}{*}{ Tando Adam } & Durgah & $32.40 \mathrm{~d}-\mathrm{f}$ & $34.72 \mathrm{~d}$ \\
& Ramaan Kirshna & $32.40 \mathrm{~d}-\mathrm{f}$ & $34.26 \mathrm{de}$ \\
& Sarahariya & $10.18 \mathrm{i}$ & $15.74 \mathrm{~h}$ \\
& Sabz Pari & $14.35 \mathrm{~h}$ & $0.00 \mathrm{j}$ \\
& Tulsi & $0.00 \mathrm{j}$ & $0.00 \mathrm{j}$ \\
& & $3.8023 \pm 1.9359$ & $0.00 \mathrm{j}$ \\
\hline
\end{tabular}

Alphabetical letters along with values indicate statistical differences among the values at $a=0.05$.

Severity of okra yellow vein mosaic disease in different okra varieties during rabi and kharif growing seasons

During the rabi growing season, all the tested varieties showed a severity score of 1 in the $8^{\text {th }}$ week of disease assessment, which gradually increased with time (Table 3). Pooja, Durgah, Ramaan Kirshna and Sarahariya showed a severity score of 4 in the last week of disease assessment (Table 3). Only the Sabz Pari variety showed minimum severity score of 2 in the $10^{\text {th }}$ and $11^{\text {th }}$ weeks of disease assessment (Table 3). However, the Tulsi variety showed a severity score of 0 (Table 3). Sarahariya, Sabz Pari, and Tulsi varieties showed a severity score of 0 during the kharif season in all the disease assessment intervals and Ramaan Kirshna showed a unique response (severity score of 1 ) at all disease assessment time points. However, Pooja and Durgah varieties showed a high severity score of 2 in the $10^{\text {th }}$ and $11^{\text {th }}$ weeks of disease assessments (Table 3). Trial-wise severity response of the disease was unique: only in the Peer Kathi trial, the disease appeared delay in the $8^{\text {th }}$ week after sowing (Table 3 ).

There was variation in disease severity in okra varieties at different trials during rabi and kharif seasons. During rabi season there was severity score of 1 in Pooja, Durgah, Ramaan Kirshna, Sarahariya and Sabz Pari varieties at Shahpur and Tando Adam trials (Table 4). However, in the Peer Kathi trial, Pooja, Durgah, Ramaan Kirshna and Sarahariya showed a maximum severity score of 2 during the rabi season (Table 4), whereas Sabz Pari variety showed the same response as that in Shahpur and Tando Adam trials. The Tulsi variety showed a severity score of 0 in all the three trials during both growing seasons (Table 4). Sarahariya and Sabz Pari varieties also showed a severity score of 0 during the kharif season, and all the remaining varieties had a severity score of 1 (Table 4). 
Table 3. Yellow vein mosaic disease severity in different okra varieties during rabi and kharif seasons.

\begin{tabular}{llllllllll}
\hline \multirow{2}{*}{ Season } & \multirow{8}{*}{ Variety } & \multicolumn{7}{c}{ Weeks after sowing } \\
\cline { 2 - 9 } & Pooja & 0 & 0 & 0 & 0 & 1 & 3 & 3 & 4 \\
& Durgah & 0 & 0 & 0 & 0 & 1 & 2 & 3 & 4 \\
& Ramaan Kirshna & 0 & 0 & 0 & 0 & 1 & 2 & 3 & 4 \\
& Sarahariya & 0 & 0 & 0 & 0 & 1 & 1 & 2 & 4 \\
& Sabz Pari & 0 & 0 & 0 & 0 & 1 & 1 & 2 & 2 \\
& Tulsi & 0 & 0 & 0 & 0 & 0 & 0 & 0 & 0 \\
\hline \multirow{6}{*}{ Kharif } & Pooja & 0 & 0 & 1 & 1 & 1 & 1 & 1 & 2 \\
& Durgah & 0 & 0 & 1 & 1 & 1 & 1 & 1 & 2 \\
& Ramaan Kirshna & 0 & 0 & 1 & 1 & 1 & 1 & 1 & 1 \\
& Sarahariya & 0 & 0 & 0 & 0 & 0 & 0 & 0 & 0 \\
& Sabz Pari & 0 & 0 & 0 & 0 & 0 & 0 & 0 & 0 \\
& Tulsi & 0 & 0 & 0 & 0 & 0 & 0 & 0 & 0 \\
\hline
\end{tabular}

* The disease severity from the first to the third week of sowing was zero.

Table 4. The severity of okra yellow vein mosaic disease in different varieties during rabi and kharif seasonsin Shahpur, Peer Kathi, and Tando Adam trials.

\begin{tabular}{|c|c|c|c|}
\hline \multirow{2}{*}{ Trial } & \multirow{2}{*}{ Variety } & \multicolumn{2}{|c|}{ Season } \\
\hline & & Rabi & Kharif \\
\hline \multirow{6}{*}{ Shahpur } & Pooja & 1 & 1 \\
\hline & Durgah & 1 & 1 \\
\hline & Ramaan Kirshna & 1 & 1 \\
\hline & Sarahariya & 1 & 0 \\
\hline & Sabz Pari & 1 & 0 \\
\hline & Tulsi & 0 & 0 \\
\hline \multirow{6}{*}{ Peer Kathi } & Pooja & 2 & 1 \\
\hline & Durgah & 2 & 1 \\
\hline & Ramaan Kirshna & 2 & 1 \\
\hline & Sarahariya & 2 & 0 \\
\hline & Sabz Pari & 1 & 0 \\
\hline & Tulsi & 0 & 0 \\
\hline \multirow{6}{*}{ Tando Adam } & Pooja & 1 & 1 \\
\hline & Durgah & 1 & 1 \\
\hline & Ramaan Kirshna & 1 & 1 \\
\hline & Sarahariya & 1 & 1 \\
\hline & Sabz Pari & 1 & 1 \\
\hline & Tulsi & 0 & 0 \\
\hline
\end{tabular}

Whitefly vector population in different okra varieties during rabi and kharif growing seasons

During the rabi growing season, whitefly appeared in the $5^{\text {th }}$ week after sowing. Population of vector in the Pooja variety during the rabi growing season ranged from 5.94 to 8.70 , after the $6^{\text {th }}$ and $7^{\text {th }}$ weeks of sowing, the values declined slightly to 5.94 (Table 5).
A similar trend of vector population was observed in other remaining varieties of okra that after $6^{\text {th }}$ week there was decline in population of vector insects during rabi growing season (Table 5). However maximum population 9 whiteflies were recorded in Ramaan Kirshna variety at $7^{\text {th }}$ week after sowing (Table 5). During kharif season vector insect appeared during $4^{\text {th }}$ 
week after sowing, but population was lower as compared to rabi season (Table 5). Maximum population was recorded in Sarahariya (5.37 whiteflies), but there was no significant difference of vector population after $8^{\text {th }}$ week of sowing until the last observation during kharif season (Table 5). A maximum of 7.21 whiteflies were recorded in $8^{\text {th }}$ week at Tando Adam trial followed by $9^{\text {th }}, 11^{\text {th }}$ and $10^{\text {th }}$ week of same trial (Table 5). However, in rabi season, the vector population slowly increased to a maximum between weeks 5 and 8 and then decreased (Table 5). In contrast, the whitefly populations in kharif season increased to a maximum around week 8 and remained similar until the end of the trial (week 11).

Table 5. Weekly population of whitefly in different okra varieties during rabi and kharif seasons.

\begin{tabular}{|c|c|c|c|c|c|c|c|c|c|}
\hline \multirow{2}{*}{ Season } & \multirow{2}{*}{ Variety } & \multicolumn{8}{|c|}{ Weeks after sowing } \\
\hline & & $4^{*}$ & 5 & 6 & 7 & 8 & 9 & 10 & 11 \\
\hline \multirow{6}{*}{ Rabi } & Pooja & $0.00 \mathrm{P}$ & $7.66 \mathrm{~F}-\mathrm{L}$ & $8.70 \mathrm{~A}-\mathrm{D}$ & $8.46 \mathrm{~A}-\mathrm{F}$ & $7.78 \mathrm{E}-\mathrm{K}$ & $6.92 \mathrm{~K}-\mathrm{Q}$ & $6.640-\mathrm{T}$ & $5.94 \mathrm{R}-\mathrm{W}$ \\
\hline & Durgah & $0.00 \mathrm{P}$ & $6.670-\mathrm{T}$ & 8.18 B-H & 8.71 A-D & 8.04 B-I & 7.31 H-P & $7.47 \mathrm{G}-0$ & $6.93 \mathrm{~K}-\mathrm{Q}$ \\
\hline & R. Kirshna & $0.00 \mathrm{P}$ & $6.83 \mathrm{~L}-\mathrm{Q}$ & $8.73 \mathrm{~A}-\mathrm{C}$ & $9.24 \mathrm{~A}$ & $8.87 \mathrm{AB}$ & $6.72 \mathrm{M}-\mathrm{S}$ & $6.46 \mathrm{P}-\mathrm{V}$ & $5.67 \mathrm{~V}-\mathrm{a}$ \\
\hline & Sarahariya & $0.00 \mathrm{P}$ & 7.23 I-P & $8.80 \mathrm{AB}$ & 8.57 A-E & 8.11 B-H & 7.88 C-J & $5.76 \mathrm{U}-\mathrm{Z}$ & $5.80 \mathrm{~T}-\mathrm{Y}$ \\
\hline & Sabz Pari & $0.00 \mathrm{P}$ & $6.89 \mathrm{~L}-\mathrm{Q}$ & 8.32 B-G & 8.59 A-E & 7.59 F-M & $7.54 \mathrm{G}-\mathrm{N}$ & 6.78 M-R & $5.89 \mathrm{~S}-\mathrm{X}$ \\
\hline & Tulsi & $0.00 \mathrm{P}$ & $6.24 \mathrm{Q}-\mathrm{V}$ & $6.70 \mathrm{~N}-\mathrm{S}$ & 7.86 D-J & 6.56 P-U & $6.610-U$ & $7.17 \mathrm{~J}-\mathrm{P}$ & $6.76 \mathrm{M}-\mathrm{S}$ \\
\hline \multirow{7}{*}{ Kharif } & Pooja & 2.820 & $3.90 \mathrm{i}-\mathrm{n}$ & $4.12 \mathrm{~h}-\mathrm{l}$ & $4.26 \mathrm{f}-\mathrm{l}$ & $4.67 \mathrm{~b}-\mathrm{i}$ & $5.10 \mathrm{~W}-\mathrm{f}$ & $4.86 \mathrm{a}-\mathrm{h}$ & $5.00 \mathrm{Y}-\mathrm{g}$ \\
\hline & Durgah & $2.92 \mathrm{o}$ & $3.61 \mathrm{j}-\mathrm{o}$ & $4.44 \mathrm{c}-\mathrm{j}$ & $4.52 \mathrm{~b}-\mathrm{i}$ & $5.02 \mathrm{X}-\mathrm{g}$ & $4.93 \mathrm{Y}-\mathrm{h}$ & $4.92 \mathrm{Z}-\mathrm{h}$ & 5.03 X-g \\
\hline & R. Kirshna & 3.18 m-o & $4.10 \mathrm{~h}-\mathrm{l}$ & $4.29 \mathrm{e}-\mathrm{k}$ & $4.43 c-j$ & $4.60 \mathrm{~b}-\mathrm{i}$ & $4.92 \mathrm{Z}-\mathrm{h}$ & $4.40 \mathrm{c}-\mathrm{j}$ & $5.24 \mathrm{~W}-\mathrm{c}$ \\
\hline & Sarahariya & 3.16 m-o & 3.49 k-o & $4.19 \mathrm{~g}-\mathrm{l}$ & $4.36 \mathrm{~d}-\mathrm{k}$ & $5.37 \mathrm{~W}-\mathrm{b}$ & $5.11 \mathrm{~W}-\mathrm{f}$ & $4.24 \mathrm{f}-\mathrm{l}$ & $5.20 \mathrm{~W}-\mathrm{d}$ \\
\hline & Sabz Pari & $3.11 \mathrm{~m}-\mathrm{o}$ & $3.97 \mathrm{i}-\mathrm{m}$ & $4.17 \mathrm{~g}-\mathrm{l}$ & $4.11 \mathrm{~h}-\mathrm{l}$ & $4.63 \mathrm{~b}-\mathrm{i}$ & $4.60 \mathrm{~b}-\mathrm{i}$ & $4.42 \mathrm{c}-\mathrm{j}$ & $5.13 \mathrm{~W}-\mathrm{e}$ \\
\hline & Tulsi & 3.07 no & $3.40 \mathrm{l}-\mathrm{o}$ & $4.31 \mathrm{e}-\mathrm{k}$ & $4.09 \mathrm{~h}-\mathrm{l}$ & $5.00 \mathrm{Y}-\mathrm{g}$ & $4.42 \mathrm{c}-\mathrm{j}$ & $4.76 \mathrm{~b}-\mathrm{i}$ & $5.32 \mathrm{~W}-\mathrm{b}$ \\
\hline & & \multicolumn{2}{|c|}{$\operatorname{LSD}(a=0.05)$} & \multicolumn{6}{|c|}{$0.8669 \pm 0.4413$} \\
\hline
\end{tabular}

R. Kirshna= Ramaan Kirshna

* The whitefly population from the first to the third week of sowing was zero. Alphabetical letters along with values indicate statistical differences among the values at $\mathrm{a}=0.05$.

Significantly higher vector population was recorded at Tando Adam trial in Sarahariya genotype (7.75) followed by Durgah (7.70), Pooja (7.67) and Ramaan Kirshna (7.36) during rabi growing season (Table 6). While minimum population of insect vector was recorded at Shahpur trial in Pooja genotype (5.23) followed by Ramaan Kirshna (5.77) and Durgah (5.84) during rabi season (Table 6). Vector population at Peer Kathi trial did not significantly vary among all the tested genotypes (Table 6).

Relationship of okra yellow vein mosaic disease severity with whitefly population

Correlation analysis showed that there was nonsignificant relationship between the disease severity and whitefly population in Ramaan Kirshna, Sarahariya and Sabz Pari varieties (Table 7). The disease severity in the
Pooja variety showed a significant relationship with vector population only in the Tando Adam trial $\left(R^{2}=\right.$ 0.7455, $P=0.0084$ ) (Table 7), whereas the Durgah variety showed a significant relationship of disease severity and vector population in Shahpur $\left(R^{2}=0.6615\right.$, $P=0.0267)$ and Tando Adam trials $\left(R^{2}=0.8235, P=\right.$ 0.0018) (Table 7). The same variety showed a nonsignificant relationship between disease severity and vector population in the Peer Kathi trial (Table 7). These results indicate that disease severity is not dependent on the population of the vector. In fact, vector appears a couple of weeks before symptom development, and even a single individual of vector may inoculate the virus into many plants. Therefore, here, most of the relationships are non-significant. 
Table 6. Population of whitefly in different varieties during rabi and kharif seasons in Shahpur, Peer Kathi, and Tando Adam locations.

\begin{tabular}{clcc}
\hline \multirow{2}{*}{ Trial } & Variety & \multicolumn{2}{c}{ Season } \\
\cline { 3 - 4 } Shahpur & Pooja & $5.23 \mathrm{ij}$ & Kharif \\
& Durgah & $5.84 \mathrm{~h}$ & $4.06 \mathrm{~lm}$ \\
& Ramaan Kirshna & $5.77 \mathrm{~h}$ & $4.11 \mathrm{~lm}$ \\
& Sarahariya & $5.72 \mathrm{hi}$ & $4.12 \mathrm{~lm}$ \\
& Sabz Pari & $6.12 \mathrm{e}-\mathrm{h}$ & $4.20 \mathrm{~lm}$ \\
& Tulsi & $5.15 \mathrm{j}$ & $4.07 \mathrm{~lm}$ \\
\hline \multirow{5}{*}{ Peer Kathi } & Pooja & $6.63 \mathrm{de}$ & $3.99 \mathrm{~m}$ \\
& Durgah & $6.45 \mathrm{efg}$ & $4.22 \mathrm{~lm}$ \\
& Ramaan Kirshna & $6.56 \mathrm{def}$ & $4.19 \mathrm{~lm}$ \\
& Sarahariya & $6.08 \mathrm{fgh}$ & $4.11 \mathrm{~lm}$ \\
& Sabz Pari & $6.01 \mathrm{gh}$ & $4.03 \mathrm{~lm}$ \\
& Tulsi & $5.77 \mathrm{~h}$ & $4.04 \mathrm{~lm}$ \\
\hline \multirow{3}{*}{ Tando Adam } & Pooja & $7.67 \mathrm{ab}$ & $4.97 \mathrm{jk}$ \\
& Durgah & $7.70 \mathrm{ab}$ & $4.93 \mathrm{jk}$ \\
& Ramaan Kirshna & $7.36 \mathrm{abc}$ & $4.87 \mathrm{jk}$ \\
& Sarahariya & $7.75 \mathrm{a}$ & $4.90 \mathrm{jk}$ \\
& Sabz Pari & $7.20 \mathrm{bc}$ & $4.56 \mathrm{kl}$ \\
& Tulsi & $7.02 \mathrm{~cd}$ & $4.77 \mathrm{jk}$ \\
\hline
\end{tabular}

Alphabetical letters along with values indicate statistical differences among the values at $a=0.05$.

Table 7. Relationship of okra yellow vein mosaic disease severity with whitefly population in different varieties of okra in Peer Kathi, Shahpur, and Tando Adam trials.

\begin{tabular}{lccc}
\hline \multirow{2}{*}{ Variety } & & Trial & \\
\cline { 2 - 4 } Pooja & Peer Kathi & Shahpur & Tando Adam \\
Durgah & $R^{2}=0.2611^{\mathrm{NS}}$ & $R^{2}=0.5442^{\mathrm{NS}}$ & $R^{2}=0.7455^{* *}$ \\
& $P=0.4380$ & $P=0.0835$ & $P=0.0084$ \\
Ramaan Kirshna & $R^{2}=0.2984^{\mathrm{NS}}$ & $P=0.6615^{*}$ & $R^{2}=0.8235^{* *}$ \\
& $P=0.3727$ & $R^{2}=0.5345^{\mathrm{NS}}$ & $P=0.0018$ \\
Sarahariya & $R^{2}=0.1522^{\mathrm{NS}}$ & $P=0.0903$ & $R^{2}=0.4392$ \\
& $P=0.6550$ & $R^{2}=0.06514$ & $P=0.1765$ \\
Sabz Pari & $R^{2}=0.3368^{\mathrm{NS}}$ & $P=0.8491$ & $R^{2}=0.1009$ \\
& $P=0.3112$ & $R^{2}=0.1303$ & $P=0.7678$ \\
Tulsi & $R^{2}=0.3619^{\mathrm{NS}}$ & $P=0.7026$ & $R^{2}=0.07522$ \\
& $P=0.2741$ & $R^{2}=0$ & $P=0.8260$ \\
& $R^{2}=0$ & $P=0$ & $R^{2}=0$ \\
& $P=0$ & $P=0$
\end{tabular}

Asterisk “**” above values indicate highly significance, “*” indicate significance and "NS" indicate no significance.

\section{DISCUSSION}

The Tulsi variety was found to be disease-free during both growing seasons. The Sabz Pari variety showed a significantly minimum incidence followed by Sarahariya and Ramaan Kirshna in the $8^{\text {th }}$ week after sowing during the rabi season. The disease incidence showed a gradual increase in all the varieties until the $11^{\text {th }}$ week of assessment. In the $11^{\text {th }}$ week of assessment, significantly 
maximum incidence was recorded in Pooja, Durgah, Ramaan Kirshna, and Sarahariya varieties followed by the Sabz Pari variety.

During the kharif season, the disease incidence was lower than that during the rabi season, but the disease appeared 2 weeks earlier in the $6^{\text {th }}$ week after sowing. Although Sarahariya and Sabz Pari varieties were found to be diseased during the rabi season, the incidence was zero during the kharif season. Although in the Peer Kathi trial the disease was delayed by 2 additional weeks to the $8^{\text {th }}$ week, but it was higher than that in Shahpur and Tando Adam trials. At terminal assessment, the maximum disease incidence was recorded in the Shahpur trial, followed by Peer Kathi and minimum incidence in the Tando Adam trial. However, significantly higher incidence of OYVMD was recorded in the Pooja during the rabi and kharif growing seasons, followed by Durgah and Ramaan Kirshna. Similarly, Pooja, Durgah, Ramaan Kirshna and Sarahariya showed a severity score of 4 in the last week of disease assessment. Only the Sabz Pari variety showed a minimum severity score of 2 in the $10^{\text {th }}$ and $11^{\text {th }}$ weeks of disease assessment. However, the Tulsi variety showed a severity score of 0 during both growing seasons. There was variation in the disease severity in okra varieties in different trials during rabi and kharif seasons. Different responses of okra varieties have been reported in previous studies, where in among test set of varieties, some showed susceptibility, while others showed resistance (Rashid et al., 2002; Mehra et al., 2008; Prashanth et al., 2008; Vijaya and Veena, 2013; Solankey et al., 2014; Kumar and Raju, 2017; Navneet and Tayde, 2018). Moreover, seasonal variation of susceptibility and resistance among okra varieties was determined by Magar and Madrap (2010), who evaluated 41 okra varieties against OYVMD. Among the 41 varieties evaluated, 18 varieties were in kharif and 35 varieties were in rabi and all 41 varieties were found to be highly resistant during summer. Local long and Pusa Sawani (check) were found to be highly susceptible in the kharif season. None were found to be highly susceptible in the rabi season. During summer season, varieties remained disease-free, which was predicated on the lack of availability of vector insect and unfavorable abiotic conditions. In our study Sabz Pari was assessed as resistant, a finding that is in affirmation with that of Ali et al. (2012) whom concluded from field trials that the variety Saloni F1 and Sabz Pari possess highly and moderately resistant potential, respectively. Diksha is the tolerant variety, while Lush Green remained moderately susceptible to OYVMD. Similarly, results of experimental locations also influenced the varietal response to the susceptibility as those of Senevirathna et al. (2016), who conducted field trials at three locations namely, Gannoruwa, Mahailluppallama, and Agunukolapelessa to screen three okra varieties resistant to OYVMD. They found that the lowest disease incidence was at Gannoruwa due to delayed infection by the virus and significant differences in severity and incidence of OYVMD among varieties as well as locations. Maximum disease incidence and severity were recorded for MI 7 and MI 5 varieties as compared to the Haritha variety, while location Mahailluppallama showed significantly high disease severity, followed by Agunukolapelessa.

Bemisia tabaci, which is the vector of this virus has a circulative mode of transmission (Cohen et al., 1989), requiring an average of $6-12 \mathrm{~h}$ before a transmission event (Fargette et al., 1996). Of the many whitefly species in the world, B. tabaci is one of the most viruliferous species, and it has now become globally distributed over all continents except the Antarctic (Martin et al., 2000). In our study, whitefly appeared in the $5^{\text {th }}$ week during the rabi growing season, and in the $4^{\text {th }}$ week during the kharif growing season. During the rabi growing season, vector population was significantly higher than that during the kharif season. A significantly higher vector population was recorded in the Tando Adam trial in the Sarahariya variety followed by Durgah, Pooja, and Ramaan Kirshna during the rabi growing season, while minimum population of insect vector was recorded in the Shahpur trial in the Pooja variety, followed by Ramaan Kirshna, and Durgah during the rabi season. Vector population in the Peer Kathi trial did not significantly vary among all the tested varieties. The correlation analysis showed that there was a nonsignificant relationship between disease severity and whitefly population in Ramaan Kirshna, Sarahariya, and Sabz Pari varieties. The disease severity in the Pooja variety showed a significant relationship with vector population only in the Tando Adam trial, whereas the Durgah variety showed a significant relationship between disease severity and vector population in Shahpur and Tando Adam trials. The same variety showed a nonsignificant relationship of disease severity and vector population in the Peer Kathi trial. In the past 
decade, whitefly-transmitted plant viruses have increased in prevalence and distribution. The recent impact has been devastating with yield losses ranging from $20 \%$ to $100 \%$, depending on the crop, season, and prevalence of the whitefly. Susceptibility of okra varieties to OYVMD encourages its incidence in the field in the presence of the active vectors (Karri and Acharyya, 2012). Temperature and rainfall influence the whitefly population dynamics (Horowitz et al., 1984; Rami Horowitz, 1986). Leaf position in the plant canopy and trichomes influences whitefly oviposition rates as well as parasitism, such as that observed in okra (Stansly et al., 1997; Leite et al., 1998). Moreover, whitefly feeding preference is also a factor that influences the disease severity. The okra variety Sabzpari harboured the minimum pest population, while Noori-786 harbored the maximum population (Mastoi et al., 2013). Similarly, among IIVR-10, IIVR-11, Hisar Unnat, Pusa A4, Versa Uphar, Pusa Sawani and Aparajita varieties of okra, Ankur-40 and Anika were highly susceptible to whitefly infestation (Nagar et al., 2017). Similarly, whitefly preferred to feed on the 317-10-1 variety and avoided the IIVR-10 variety (Navneet and Tayde, 2018). Furthermore, Ali et al. (2005b) analyzed the relationship of environmental conditions with severity of BYVMV and its vector insect on different commercially cultivated varieties of okra. Minimum temperature and relative humidity were significantly related to severity of BYVMV and its vector insect. The disease incidence increased with the increase in minimum temperature, and the population of vector insect decreased with increase in the relative humidity. Surkh Bindi was found to be highly resistant among the okra cultivars. This result indicated that severity of the disease is not dependent on the population of vector. In fact, the vector appears a couple of weeks before symptom development, and even a single individual of vector may inoculate the virus to many plants. Therefore, here, most of the relationships are nonsignificant.

\section{CONCLUSIONS}

On the basis of the results of the present study, it is concluded that Pooja, Durgah, and Ramaan Kirshna varieties are susceptible to OYVMD. Tulsi and Sabz Pari, and Sarahariya varieties are resistant to the disease. The disease appears 2 to 4 weeks after appearance of vector insect in the crop. The disease intensity was higher during rabi than during kharif. The Peer Kathi location was the most favorable for the disease development. The vector insect was found in all the varieties during both growing seasons. Even though the Tulsi variety was disease free, whitefly infested the variety during both growing seasons. Moreover, the disease severity was not related to vector population in Ramaan Kirshna, Sarahariya, and Sabz Pari varieties, but it showed a relationship in remaining varieties at individual locations of trials.

\section{ACKNOWLEDGMENT}

The authors are highly thankful to Professor Dr. Wang Xifeng for extending support in detecting the virus for confirmation in his laboratory. This work is part of Master's thesis submitted to department of Plant Pathology, Faculty of Crop Protection, Sindh Agriculture University, Tandojam 70600, Pakistan.

\section{REFERENCES}

Akram, M., F. Hafeez, M. Farooq, M. Arshad, M. Hussain, S. Ahmed, K. Zia and H. A. Ali Khan. 2013. A case to study population dynamics of Bemisia tabaci and Thrips tabaci on Bt and non-Bt cotton genotypes. Pakistan Journal of Agricultural Sciences, 50: 61723.

Ali, S., M. Khan, A. Habib, S. Rasheed and Y. Iftikhar. 2005a. Correlation of environmental conditions with okra yellow vein mosaic virus and Bemisia tabaci population density. International Journal of Agriculture and Biology, 7: 142-44.

Ali, S., M. Khan, A. Habib, S. Rasheed and Y. Iftikhar. 2005b. Management of yellow vein mosaic disease of okra through pesticide/bio-pesticide and suitable cultivars. International Journal of Agriculture and Biology, 7: 145-47.

Ali, T. H., O. S. Balogun and L. Kumar. 2012. Survey of the symptoms and viruses associated with cowpea (Vigna Unguiculata (L).) in the agro ecological zones of Kwara state, Nigeria. Ethiopian Journal of Environmental Studies and Management, 5: 61319.

Cohen, S. M., G. Brönner, F. Küttner, G. Jürgens and H. Jäckle. 1989. Distal-less encodes a homoeodomain protein required for limb development in Drosophila. Nature, 338: 432-34.

Cooke, B. M., D. G. Jones and B. Kaye. 2006. The Epidemiology of Plant Diseases. Springer.

FAOSTAT. 2020. FAO Production Year Book. Food and 
Agriculture Organization of the United Nations. Rome, Italy.

Fargette, D., M. Leslie and B. D. Harrison. 1996. Serological studies on the accumulation and localisation of three tomato leaf curl geminiviruses in resistant and susceptible Lycopersicon species and tomato cultivars. Annals of Applied Biology, 128: 317-28.

Ghosh, R., S. Paul, S. K. Ghosh and A. Roy. 2009. An improved method of DNA isolation suitable for PCR-based detection of begomoviruses from jute and other mucilaginous plants. Journal of Virological Methods, 159: 34-39.

González-Pérez, J., M. Espino-Gudiño, L. Torres-Pacheco, R. Guevara-González, G. Herrera-Ruiz and V. Rodríguez-Hernández. 2011. Quantification of virus syndrome in chili peppers. African Journal of Biotechnology, 10: 5236-50.

GOP. 2020. Fruit, vegetables and condiments statistics of Pakistan. Government of Pakistan Ministry of National Food Security and Research Economic Wing. Islamabad, Pakistan.

Horowitz, A. R., H. Podoler and D. Gerling. 1984. Life table analysis of the tobacco whitefly Bemisia tabaci (Gennadius) in cotton fields in Israel. Acta oecologica. Oecologia applicata, 5: 221-33.

Karri, S. R. and P. Acharyya. 2012. Incidence of Yellow Vein Mosaic Virus disease of Okra (Abelmoschus esculentus (L.) Moench] under summer and rainy environment. International Journal of Current Research, 4: 018-21.

Khaskheli, M., M. Jiskani, S. Goswami, G. Poussio and M. Khaskheli. 2017. Effect of Okra Yellow Vein Mosaic Virus (OYVMV) on plant growth and yield. Journal of Basic and Applied Sciences, 13: 1-7.

Kumar, S. and S. V. S. Raju. 2017. Screening of certain okra genotypes against Yellow Vein Mosaic Virus disease under field conditions. International Journal of Current Microbiology and Applied Sciences, 6: 1461-66.

Kumbhar, A. A. 2017. Prevalence of okra yellow vein mosaic viral disease in sindh and its correlation with vector population, Sindh Agriculture University.

Leite, G. L. D., M. Picanço, J. C. Zanuncio and A. H. R. Gonring. 1998. Effect of fertilization levels, age and canopy height of Lycopersicon spp. on attack rate of Bemisia tabaci (Homoptera: Aleyrodidae).
Agronomia Lusitana, 46: 53-60.

Magar, R. G. and I. A. Madrap. 2010. Performance of okra in relation to yellow vein mosaic virus in different seasons. International Journal of Plant Sciences, 5: 33-35.

Martin, J. H., D. Mifsud and C. Rapisarda. 2000. The whiteflies (Hemiptera: Aleyrodidae) of Europe and the Mediterranean basin. Bulletin of Entomological Research, 90: 407-48.

Mastoi, A. H., S. A. Memon and W. Haq. 2013. Varietal resistance of okra against whitefly (Bemisia tabaci) and fruit borer (Earias spp). Scholarly Journal of Agricultural Science, 3: 78-82.

Mehra, R., D. Poonam and B. Vinod. 2008. Screening of okra germplasm against okra yellow vein mosaic virus and okra leaf curl virus diseases for sustainable cultivation. Haryana Journal of Horticultural Sciences, 37: 121-22.

Nagar, J., S. K. Khinchi, K. C. Kumawat and A. Sharma. 2017. Screening different varieties of okra [Abelmoschus esculentus (L.) Moench] against sucking insect pests. Journal of Pharmacognosy and Phytochemistry, 6: 30-34.

Navneet and A. R. Tayde. 2018. Screening of okra genotypes against white fly [Bemisia tabaci [Gennadius)] and YVM Virus. Journal of Entomology and Zoology Studies, 6: 565-68.

Prakasha, T. L., M. S. Patil and V. I. Benagi. 2010. Survey for bhendi yellow vein mosaic disease in parts of Karnataka. Karnataka Journal of Agricultural Sciences, 23: 658-59.

Prashanth, S. J., R. P. Jaiprakashnarayan, M. Ravindra and M. B. Madalageri. 2008. Screening for disease in incidence of yellow vein mosaic virus in okra [Abelmoschus esculentum (L.) Moench]. International Journal of Plant Protection, 1: 78-80.

Pun, K. B. and S. Doraiswamy. 1999. Effect of age of okra plants on susceptibility to Okra yellow vein mosaic virus. Indian Journal of Virology, 15: 5758.

Rami Horowitz, A. 1986. Population dynamics of Bemisia tabaci (Gennadius) with special emphasis on cotton fields. Agriculture, Ecosystems \& Environment, 17: 37-47.

Rashid, M. H., L. Yasmin, M. G. Kibria, A. K. M. S. R. Mollik and S. M. M. Hossain. 2002. Screening of okra germplasm for resistance to Yellow Vein Mosaic Virus under field conditions. Plant Pathology 
Journal, 1: 61-62.

Sangeeta, S. and A. K. Tiwari. 2017. Transmission of Begomoviruses. In, Begomoviruses: Occurrence and Management in Asia and Africa. Springer.

Senevirathna, H. M. S. I., S. K. Wasala, D. M. J. B. Senanayake, D. Weerasekara, H. A. M. Wickamasinghe and P. K. G. A. Deepal. 2016. Characterization and detection of Yellow Vein Disease of okra (Abelmoschus esculentus (L.) Moench) in Sri Lanka. Tropical Agricultural Research, 27: 360-69.

Siddique, F., S. Ali, M. Ehetisham-ul-Haq, M. Atiq and A. Rashid. 2016. Epidemiological characterization of Okra Yellow Vein Mosaic Virus and its vector. Advances in Environmental Biology, 10: 194-203.
Solankey, S. S., A. Shirin, K. Randhir, B. V. R and S. Kumar. 2014. Seasonal response of okra (Abelmoschus esculentus L. Moench) genotypes for okra yellow vein mosaic virus incidence. African Journal of Biotechnology, 13: 1336-42.

Stansly, P. A., D. J. Schuster and T.-X. Liu. 1997. Apparent parasitism of Bemisia argentifolii (Homoptera: Aleyrodidae) by Aphelinidae (Hymenoptera) on vegetable crops and associated weeds in South Florida. Biological Control, 9: 49-57.

Vijaya, M. and J. Veena. 2013. Screening for yellow vein mosaic virus resistance of okra under Hyderabad conditions. Asian Journal of Horticulture, 8: 76366.

\section{CONFLICT OF INTEREST}

The authors declare that they have no conflicts of interest.

\section{AUTHORS CONTRIBUTIONS}

All authors contributed to the study conception and design. Material preparation and data collection were performed by Sabir Iqbal Khoso, Ali Asghar Lakho. Analysis was performed by Jamal-U-Ddin Hajano, Manzoor Ali Abro, Khalid Hussain Dhiloo, Fahad Nazir Khoso, Khadim Hussain Wagan and Aftab Raza Jarwar. The first draft of the manuscript was written by Sabir Iqbal Khoso, Suman Tarique Qazi and Syed Rizwan and all authors commented on previous versions of the manuscript. All authors read and approved the final manuscript.

Publisher's note: EScience Press remains neutral with regard to jurisdictional claims in published maps and institutional affiliations.

Open Access This article is licensed under a Creative Commons Attribution 4.0 International License, which permits use, sharing, adaptation, distribution and reproduction in any medium or format, as long as you give appropriate credit to the original author(s) and the source, provide a link to the Creative Commons license and indicate if changes were made. The images or other third-party material in this article are included in the article's Creative Commons license, unless indicated otherwise in a credit line to the material. If material is not included in the article's Creative Commons license and your intended use is not permitted by statutory regulation or exceeds the permitted use, you will need to obtain permission directly from the copyright holder. To view a copy of this license, visit http://creativecommons.org/licenses/by/4.0/. 